\title{
INFLUENCE OF WIND-DRIVEN RAIN ON THE THERMAL CONDUCTIVITY OF BUILDING ENVELOPES WITH DIFFERENT CEMENT-LIME COATINGS
}

This paper deals with influence of the wind-driven rain on the building envelopes in terms of thermal conductivity. Low rise building was simulated in Computational fluid dynamics CFD software OpenFOAM using Eulerian multiphase model for rain phase and determined rain load was used as an input for Heat-Air-Moisture HAM simulation in WUFI. Two different wall constructions which were used differ in the core layer and also in exterior coatings. The influence of wind-driven rain load on the thermal conductivity for aerated concrete and aerated clay brick was established.

Keywords: Wind-driven rain, CFD, precipitation, rainfall, Eulerian multiphase model, TRY, heat-air moisture simulation, HAM, cementlime coating.

\section{Introduction}

Wind-driven rain (WDR) can be an important moisture source for building facades and therefore is of great concern in civil engineering. Wind-driven rain or driving rain is rain that is given a horizontal velocity component by wind. WDR intensity depends on several parameters such as building geometry, surroundings, terrain topography, position on the facade, wind velocity, wind direction, rainfall intensity and raindrop-size distribution. Wind-driven rain research is important within a number of research areas including Earth sciences, meteorology and building science. As one of the most important moisture sources, it affects the hydrothermal performance and durability of facades. Consequences of its destructive effect can take many forms. Moisture accumulation in porous materials can lead to water penetration, frost damage, moisture induced salt migration, discoloration by efflorescence, structural cracking due to thermal and moisture gradients, increased thermal lost due to the raised thermal conductivity, aesthetics etc. [1 and 2].

Computational Fluid Dynamics (CFD) simulations can be a valuable alternative to measurements and semi-empirical methods. According to the STN EN 15026 [3], WDR load should be involved in building envelope heat-air-moisture (HAM) simulation. This leads to the need for accurate information on the spatial distribution of surface wetting and, therefore, CFD simulations with their high resolution are very useful.

The use of various simulation programs has increased with development of computers. Programs for simulation of heat-air and moisture transport in building envelope uses non-steady boundary condition - outdoor climate data sets - test reference years (TRY) [4]. Test reference years are used in building science for many purposes. Generally, there are two types of test reference years: energy TRY (to calculate the energy consumption) and moisture reference year (to analyze the moisture problems in building envelopes). The methodology for creation of moisture TRY from long term observation is analyzed and described by Sanders [4].

This paper deals with influence of WDR on the building envelope in terms of thermal conductivity. Low rise building was simulated in CFD software OpenFOAM using Eulerian multiphase model for rain phase and determined rain load was used as an input for HAM simulation in WUFI. Two different wall constructions which were used differ in the core layer and also in exterior coatings. The influence of wind-driven rain load on the thermal conductivity for the aerated concrete and aerated clay brick was established.

\section{Computational domain}

The computational domain for the simulated building with dimensions $775 \times 1600 \times 420 \mathrm{~m}$ is shown in Fig. 1 and consists of $4,876,875$ tetrahedral cells. The blockage ratio of the domain is $0.1 \%$ and the distances of the modelled building between the domain boundaries are according to the guidelines of Franke et al. [5].

\footnotetext{
* ${ }^{1}$ Peter Juras, ${ }^{2}$ Pavol Durica

${ }^{1}$ Research Centre, University of Zilina, Slovakia

${ }^{2}$ Department of Building Engineering and Urban Planning,, Faculty of Civil Engineering, University of Zilina, Slovakia

E-mail: peter.juras@rc.uniza.sk
} 


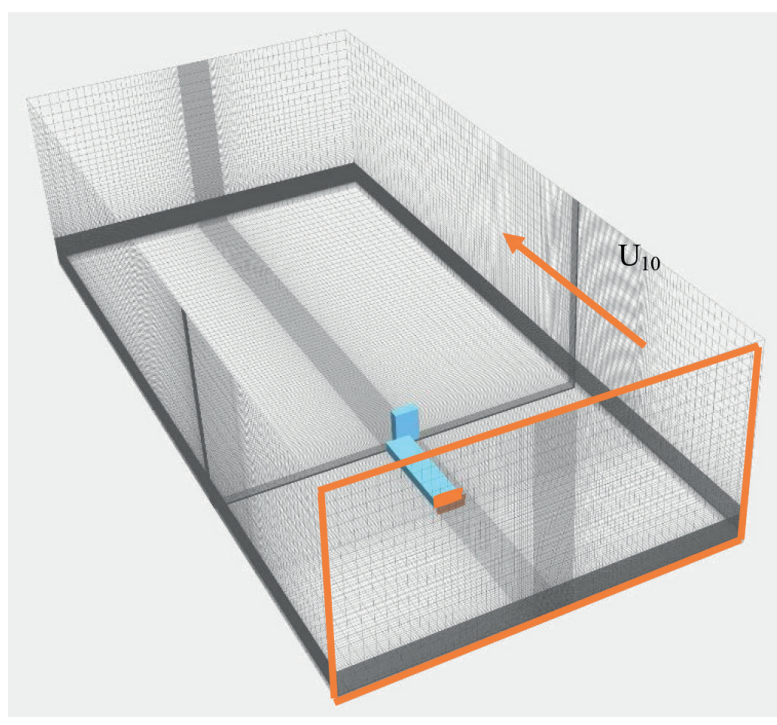

Fig. 1 Computational domain with dimension $775 \times 1600 \times 420 \mathrm{~m}$ and marked investigated windward facade, inlet plane with flow direction and wind velocity $U_{10}=10 \mathrm{~m} / \mathrm{s}$

\section{Reference wall constructions}

Two walls with two different traditional coatings (totally four variants) from Baumit were used for the heat-air and moisture simulation (HAM) - see Table 1. The basic difference between EdelPutz and FeinPutz is the final surface of the coating. The material base is more or less the same. FeinPutz has smooth and EdelPutz scraped surface. The material parameters are summarized in Table 2. The measured properties from previous research [6 and 7] are highlighted. The rest of properties are from the WUFI software database, mostly measured by Fraunhofer Institute for Building Physics.

\section{Wind and rain phase}

Computer code OpenFOAM was used for numerical simulation. It is an open-source, implicit, segregated and double precision solver. Eulerian multiphase model [8] was used for the rain phase instead of commonly used and more time consuming Langrangian particle tracking model. This model enables to reduce the computational expense to model a long rain event which is discretised into $1 \mathrm{~min}$ or $10 \mathrm{~min}$ time steps. CFD simulations are made for a limited number of horizontal rainfall intensity and wind velocity couples. The wind-flow field in the domain is solved for wind velocity $U_{10}=10 \mathrm{~m} / \mathrm{s}$ and wind-flow fields for other reference wind velocities $(1,2,3$ and $10 \mathrm{~m} / \mathrm{s})$ are obtained by linear scaling.

In Fig. 2, we can see a wind flow field showing the mean wind velocity on the vertical mid-plane through both buildings. The wind flow on the high building is clearly influenced by the lower building. Typical flow features as the standing vortex, the downflow from the stagnation point, large vortices behind the building, and flow restoration behind the building are visible.

Detailed construction of the reference walls

Table 1

\begin{tabular}{|c|c|c|c|c|c|}
\hline $\begin{array}{c}\text { Aerated clay } \\
\text { brick wall }\end{array}$ & TSF & $\begin{array}{c}\text { FeinPutz - smooth coating } \\
\text { th. } 5 \mathrm{~mm}\end{array}$ & GrobPutz th. $20 \mathrm{~mm}$ & $\begin{array}{c}\text { Aerated clay brick (ACB) } \\
\text { th. } 365 \mathrm{~mm}\end{array}$ & Gypsum plaster th. $15 \mathrm{~mm}$ \\
\hline $\begin{array}{c}\text { Aerated clay } \\
\text { brick wall }\end{array}$ & TSE & $\begin{array}{c}\text { EdelPutz - scraped coating } \\
\text { th. } 10 \mathrm{~mm}\end{array}$ & MVR Uni th. $15 \mathrm{~mm}$ & $\begin{array}{c}\text { Aerated clay brick (ACB) } \\
\text { th. } 365 \mathrm{~mm}\end{array}$ & Gypsum plaster th. $15 \mathrm{~mm}$ \\
\hline $\begin{array}{c}\text { Aerated } \\
\text { concrete wall }\end{array}$ & PSF & $\begin{array}{c}\text { FeinPutz - smooth coating } \\
\text { th. } 5 \mathrm{~mm}\end{array}$ & GrobPutz th. $20 \mathrm{~mm}$ & $\begin{array}{c}\text { Aerated concrete }(\mathrm{ACC}) \\
\text { th. } 365 \mathrm{~mm}\end{array}$ & Gypsum plaster th. $15 \mathrm{~mm}$ \\
\hline $\begin{array}{c}\text { Aerated } \\
\text { concrete wall }\end{array}$ & PSE & $\begin{array}{c}\text { EdelPutz } \text { - scraped coating } \\
\text { th. } 10 \mathrm{~mm}\end{array}$ & MVR Uni th. $15 \mathrm{~mm}$ & $\begin{array}{c}\text { Aerated concrete }(\mathrm{ACC}) \\
\text { th. } 365 \mathrm{~mm}\end{array}$ & Gypsum plaster th. $15 \mathrm{~mm}$ \\
\hline
\end{tabular}

Material properties of used materials

Table 2

\begin{tabular}{|c|c|c|c|c|c|c|}
\hline Name & $\begin{array}{c}\text { Bulk density } \\
\left(\mathrm{kg} / \mathrm{m}^{3}\right)\end{array}$ & Porosity $(-)$ & $\begin{array}{c}\text { Thermal } \\
\text { conductivity }(\text { dry } \\
\text { state } \lambda(\mathrm{W} /(\mathrm{m} . \mathrm{K})\end{array}$ & $\begin{array}{c}\text { Diffusion resistance } \\
\text { factor } \mu(-)\end{array}$ & $\begin{array}{c}\text { Water absorption } \\
\text { coefficient } \\
\mathrm{A}\left(\mathrm{kg} / \mathrm{m}^{2} \mathrm{~s}^{0.5}\right)\end{array}$ & $\begin{array}{c}\text { Capillary } \\
\text { water content } \\
\mathrm{w}_{\text {cap }}\left(\mathrm{kg} / \mathrm{m}^{3}\right)\end{array}$ \\
\hline EdelPutz & $\mathbf{1 3 0 3}$ & $\mathbf{0 . 1 1}$ & 0.8 & 15 & $\mathbf{0 . 0 1 2 3}$ & $\mathbf{7 1 . 3 1}$ \\
\hline FeinPutz & $\mathbf{1 3 6 1}$ & $\mathbf{0 . 1 7}$ & 0.5 & 20 & $\mathbf{0 . 0 2 6 1}$ & $\mathbf{1 1 0 . 2 4}$ \\
\hline Grobputz & $\mathbf{1 5 6 8}$ & $\mathbf{0 . 2 2}$ & 0.9 & 20 & $\mathbf{0 . 1 5 8 3}$ & $\mathbf{2 0 3 . 3 6}$ \\
\hline MVR Uni & $\mathbf{1 0 1 5}$ & $\mathbf{0 . 1 8}$ & 0.5 & 20 & $\mathbf{0 . 0 1 5 4}$ & $\mathbf{1 0 9 . 5 5}$ \\
\hline ACB & 600 & 0.77 & 0.12 & 16 & - & 188 \\
\hline ACC & 400 & 0.81 & 0.1 & 7.9 & - & 380 \\
\hline gypsum plaster & 850 & 0.65 & 0.2 & 8.3 & - & 400 \\
\hline
\end{tabular}




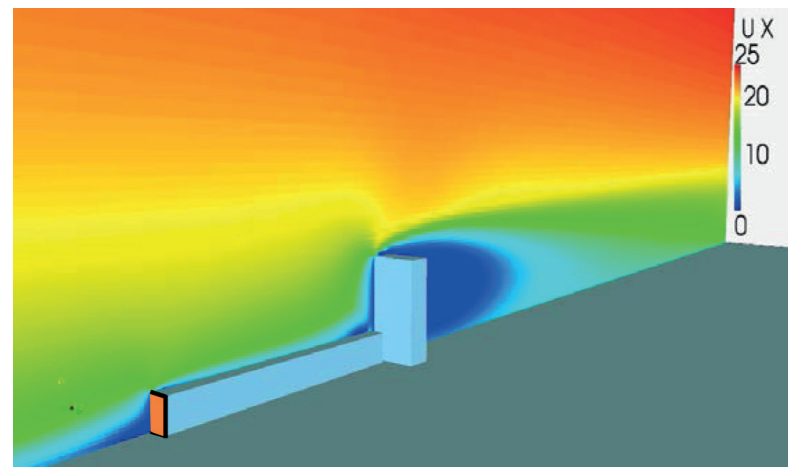

Fig. 2 Wind flow field through vertical plane. Reference wind velocity $U_{10}=10 \mathrm{~m} / \mathrm{s}$; marked windward's north-west facade of investigated lowrise building

The inlet profile of the mean wind velocity is defined by the typical log-law expression [9]:
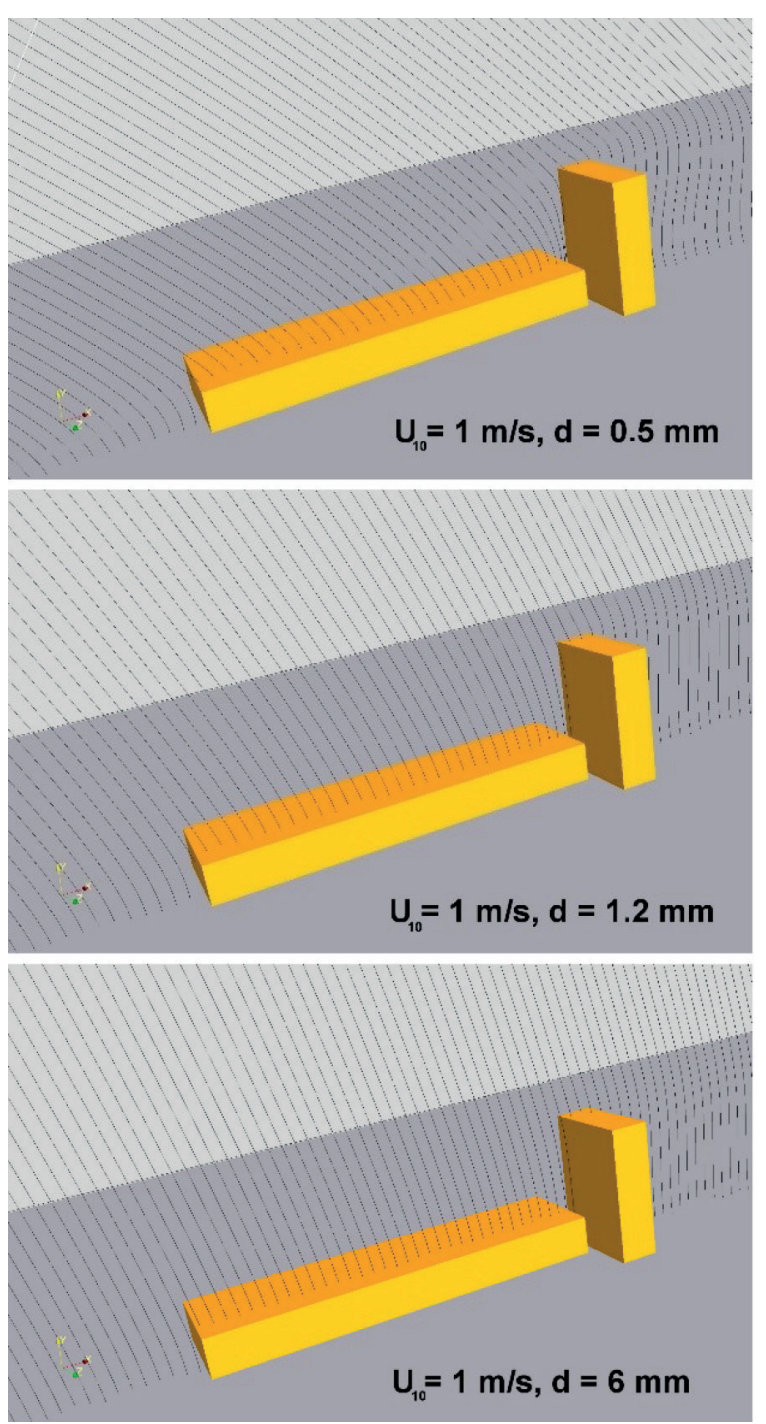

$U(y)=\frac{u^{*} A B L}{k} \ln \left(\frac{y+y_{0}}{y_{0}}\right)$

where $U(y)$ is the mean streamwise wind velocity at height $y$ above the ground plane, $u^{*}{ }_{A B L}$ the ABL friction velocity, $k$ the von Karman constant (used 0.41 in the present study), and $\mathrm{y}_{0}$ the aerodynamic roughness length. In the paper, an aerodynamic roughness length of 0.5 is chosen which represents a landscape totally and quite regularly covered with similar-size large objects according to the Davenport roughness classification [10 and 11]. The Aerodynamic boundary layer (ABL) friction velocity, $u^{*}{ }_{A B L}$, is chosen to obtain the desired reference wind speed, $U_{10}$, at a height of $10 \mathrm{~m}$ (in this study $10 \mathrm{~m} / \mathrm{s}$ ).

In Fig. 3 we can see the difference of raindrop trajectories with different wind velocity and raindrop diameter. The higher the wind velocity, the more inclined the trajectories are. Behind the obstruction the turbulent flow occurs which influences the
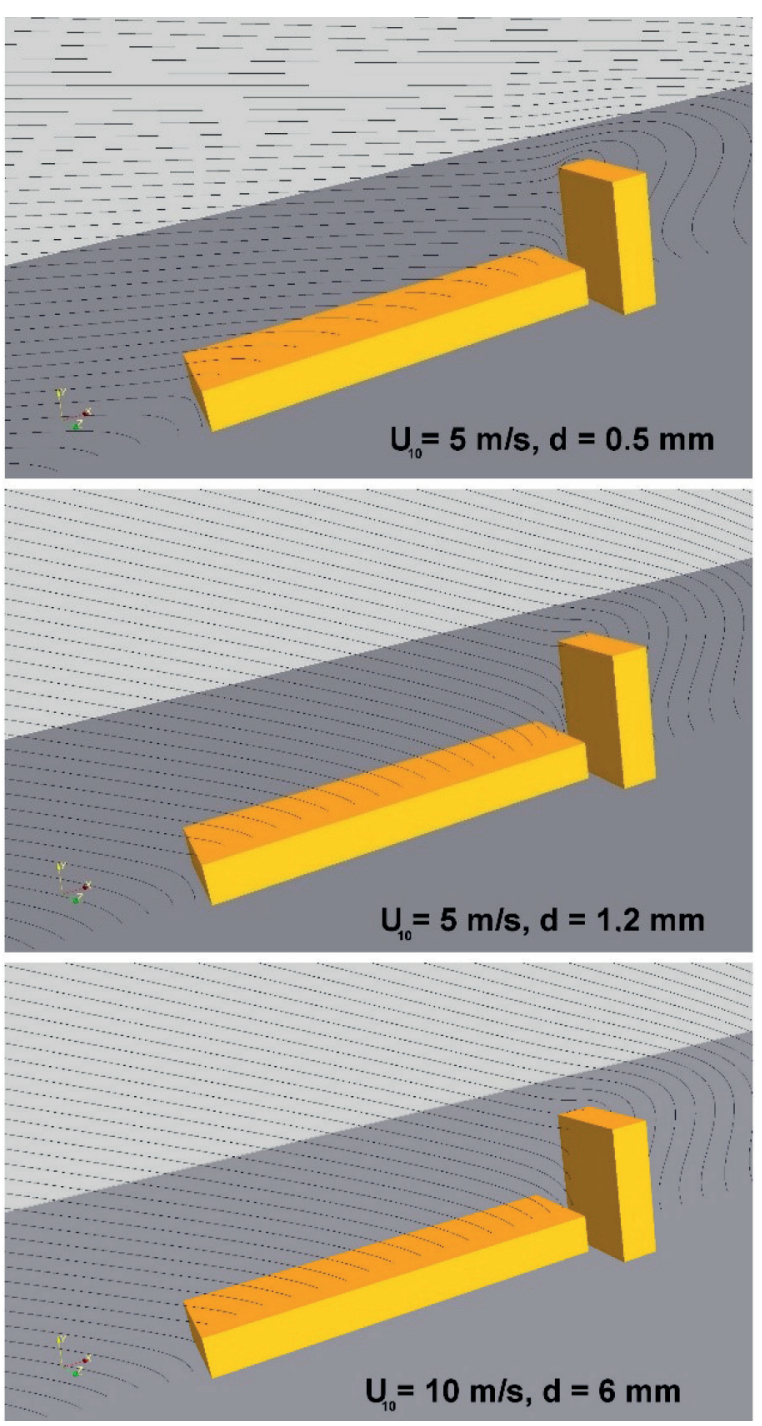

Fig. 3 Raindrop trajectories for selected wind velocity and raindrop diameter 
a)

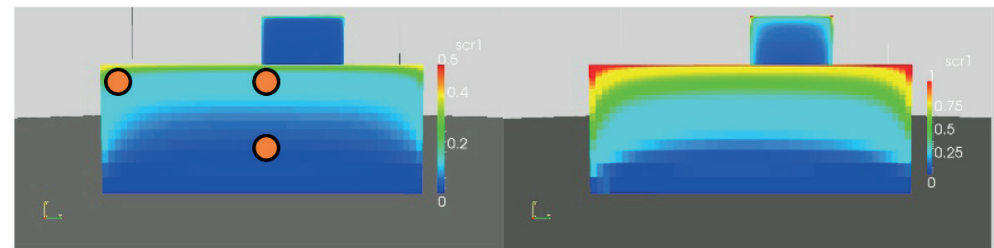

d)

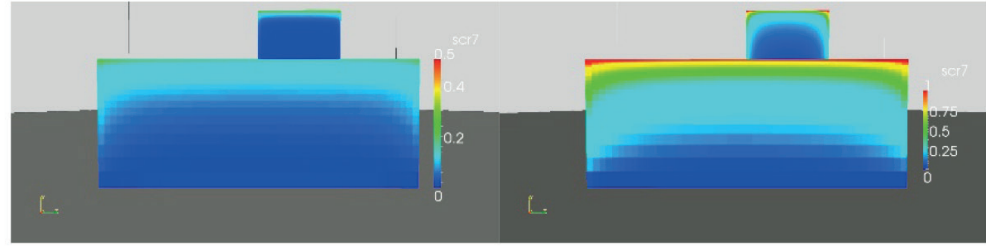

g)

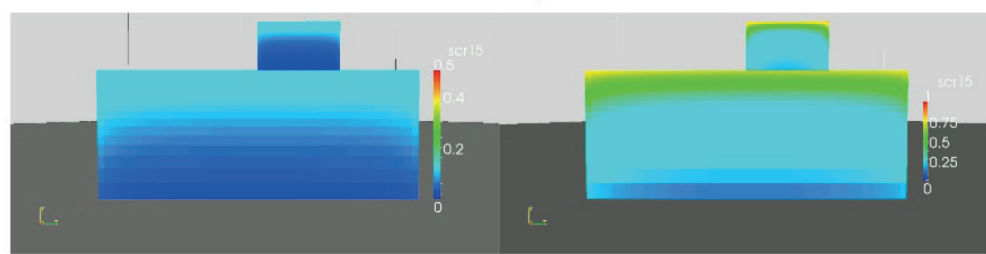

c)

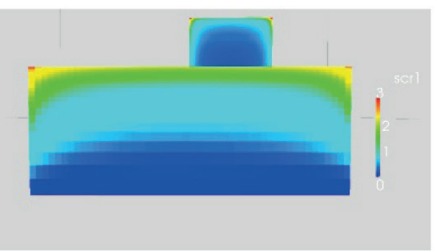

f)

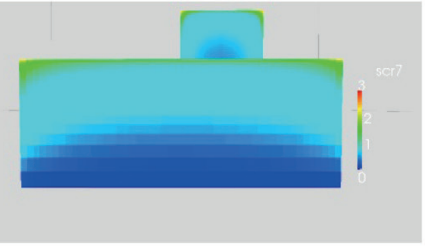

i)

Fig. 4 Specific catch ratio $\eta_{d}$ on the low rise building facade for the selected wind velocity and raindrop diameter: a) $U 10=1 \mathrm{~m} / \mathrm{s}, d=0.5 \mathrm{~mm}$; b) $U 10=5 \mathrm{~m} / \mathrm{s}, d=0.5 \mathrm{~mm}$; c) $U 10=10 \mathrm{~m} / \mathrm{s}, d=0.5 \mathrm{~mm}$; d) $U 10=1 \mathrm{~m} / \mathrm{s}, d=1.2 \mathrm{~mm} ; \mathrm{e}) U 10=5 \mathrm{~m} / \mathrm{s}, d=1.2 \mathrm{~mm}$; f) $U 10=10 \mathrm{~m} / \mathrm{s}, d=1.2 \mathrm{~mm}$; g) $U 10=1 \mathrm{~m} / \mathrm{s}, d=6 \mathrm{~mm}$; h) $U 10=5 \mathrm{~m} / \mathrm{s}, d=6 \mathrm{~mm} ;$ i) $U 10=10 \mathrm{~m} / \mathrm{s}, d=6 \mathrm{~mm}$

trajectories. With using each reference wind-flow field, specific catch ratio distributions are calculated for various diameters (Fig. 4) of raindrops (diameters from 0.5 to $1 \mathrm{~mm}$ in steps of $0.1 \mathrm{~mm}$, from 1 to 2 in steps of 0.2 and from 2 to 6 in steps of $1 \mathrm{~mm}$ ). Catch ratio distributions are obtained for a list of reference horizontal rainfall intensities $R_{h}(0,0.1,0.5,1,2,3,4$, $5,6,8,10,12,15,20,25$, and $30 \mathrm{~mm} / \mathrm{h}$, catch ratio chart in Fig. 5) using the droplet size distribution as input [12]. The global catch ratio for selected rain event is obtained by summation over all the time steps in the rain event (inputs are wind velocity, wind direction and rainfall on the horizontal plane) [8 and 13].

\section{Determination of wind-driven rain load}

The global catch ratios for six positions on the facade (Fig. 5) are summarized in Table 3. It was obtained through the numerical model for the measured rain event on 4-5 November 2012 [12].
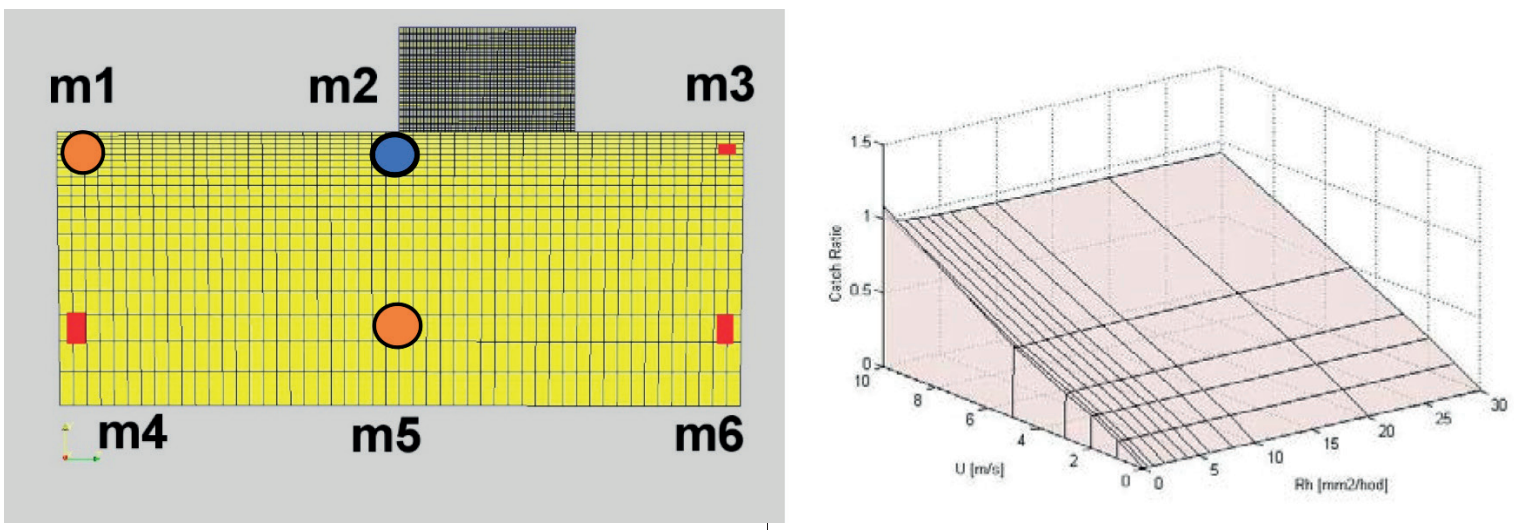

Fig. 5 Position of selected cells on low-rise building facade from Table 3 and catch ratio chart for the position $m 2$; the charts represent $R_{w d} / R_{h}$ as function from rain intensity and wind velocity 
Catch ratio and proportion factor for the selected locations in Fig. 5

Table 3

\begin{tabular}{|c|c|c|c|c|}
\hline Position on facade & Cell number & catch ratio $\boldsymbol{\eta}=\mathbf{R}_{\text {wdr }} / \mathbf{R}_{\mathbf{h}}$ & proportion factor $\boldsymbol{a}$ & height above the terrain $(\mathbf{m})$ \\
\hline $\mathbf{m} 1$ & $\mathbf{1 2 3 6}$ & $\mathbf{0 . 7 8 4}$ & $\mathbf{0 . 2 3 8}$ & $\mathbf{1 8}$ \\
\hline $\mathrm{m} \mathbf{1 6 9 4}$ & $\mathbf{0 . 5 5 8}$ & $\mathbf{0 . 1 6 9}$ & $\mathbf{1 8}$ \\
\hline $\mathrm{m} 3$ & 6575 & 0.711 & 0.216 & 18 \\
\hline $\mathrm{m} 4$ & 1222 & 0.227 & 0.069 & 5 \\
\hline $\mathrm{m} 5$ & $\mathbf{1 6 8 3}$ & $\mathbf{0 . 1 7 0}$ & $\mathbf{0 . 0 5 2}$ & $\mathbf{5}$ \\
\hline $\mathrm{m} 6$ & 6562 & 0.203 & 0.062 & 5 \\
\hline
\end{tabular}

More detailed information about the rain event is stated in [12]. The rain lasted for 9 hours with cumulative horizontal rainfall $44.5 \mathrm{~mm} / \mathrm{m}^{2}$.

From Fig. 4, which represents specific catch ratios, we can clearly see the difference of WDR load on the facade which is highest in the upper part and especially in the top corners. For the determination of WDR load on the facade, three positions on the facade were selected (Fig. 5), concretely $m 1$ with the highest catch ratio, $m 2$ with overall value for the upper part and $m 5$ for the lower part of the building. Catch ratio chart for the position $m 2$ is shown in Fig. 5 and it depends on the wind velocity and rain intensity. The catch ratios from the numerical model are transformed to the proportion factor (Table 3). The proportion factor in the HAM simulation program WUFI defines the position on the facade.

\section{HAM simulation in WUFI}

For simulation in WUFI software, two different wall types with different coatings were used. According to the previous research [14], climatic year 2010 for Bratislava (mean temperature $9.5^{\circ} \mathrm{C}$, horizontal rain sum $1012 \mathrm{~mm} / \mathrm{m}^{2}$ ) were used as the outer boundary condition. As input for the numerical model was used only rainfall with corresponding wind direction (wind-driven rain which affects the facade -raindrops hit the windward north-west facade). The initial moisture for used materials was typical built-in moisture according to the WUFI database. The inner boundary condition was derived from outer according to the STN EN 15026:2007. Figs. 6 and 7 represent the average annual course of water content in the core layer (ACB and ACC) in the $5^{\text {th }}$ year after the construction of building. Table 4 shows the annual averages of water content for selected positions.

Mean annual water content in the core layer

of simulated walls

Table 4

\begin{tabular}{|c|c|c|c|c|}
\hline$\left[\mathrm{kg} / \mathrm{m}^{3}\right]$ & TSE & TSF & PSE & PSF \\
\hline $\boldsymbol{m} \mathbf{a}=\mathbf{0 . 2 3 8}$ & 45.86 & 49.76 & 78.54 & 38.26 \\
\hline $\boldsymbol{m} \mathbf{a}=\mathbf{0 . 1 6 9}$ & 42.04 & 42.20 & 69.28 & 28.39 \\
\hline $\boldsymbol{m} \mathbf{a}=\mathbf{0 . 0 5 2}$ & 27.06 & 15.06 & 31.76 & 8.86 \\
\hline
\end{tabular}

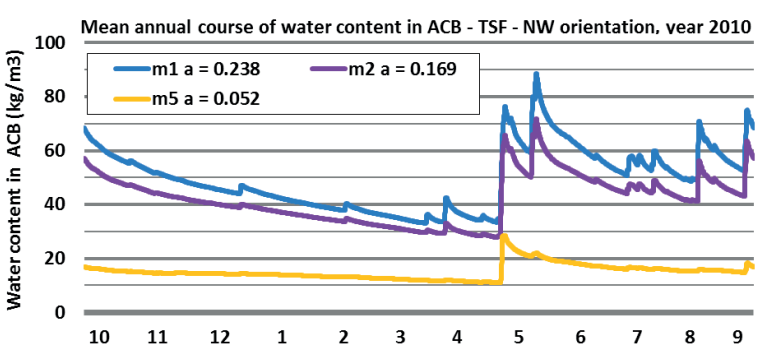

Fig. 6 Mean annual course of water content in aerated clay brick $(A C B)$ wall TSF for the three selected positions on facade with exterior smooth coating FeinPutz

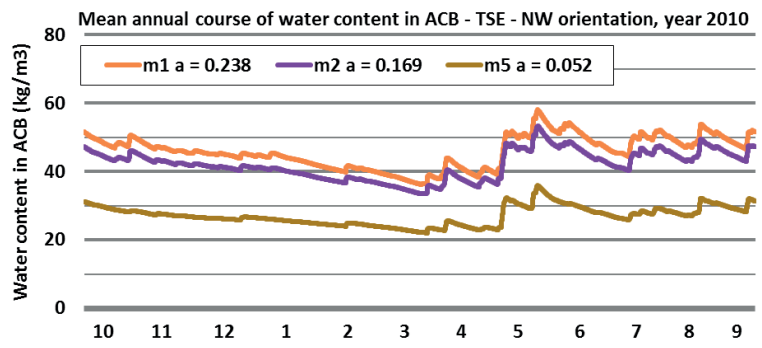

Fig. 7 Mean annual course of water content in aerated clay brick $(A C B)$ wall TSE for the three selected positions on facade with exterior scraped coating EdelPutz

\section{Results and discussions}

From Figs. 6 and 7 we can clearly see the difference between the WDR load and its influence on the water content in the aerated clay brick. In Tables 5 and 6 we can see how the increased water content is reflected in thermal conductivity (Fig. 8), especially in the upper positions and the aerated clay brick wall where the difference is very big. The thermal resistance decreases up to $45 \%$ for the aerated clay brick wall (TSF) with smooth FeinPutz coatings. With the aerated concrete wall, the values are not so high. In the bottom part of the building $(\mathrm{m} 5)$, the values of thermal conductivity are significantly lower. 
Thermal conductivity dependence on the water content in material

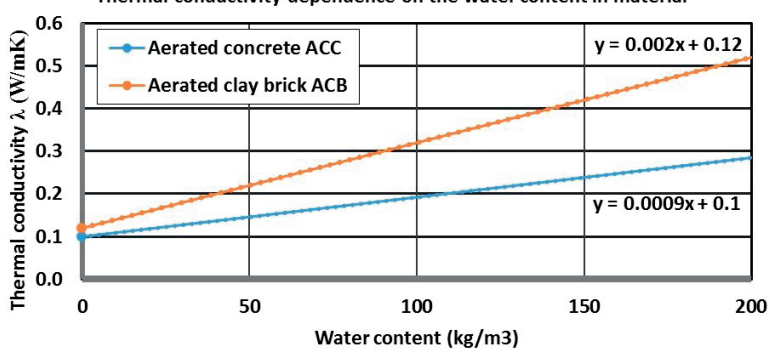

Fig. 8 Thermal conductivity dependence on water content in material Source: WUFI database

Difference between dry values and values according to the average water content for position $m l$

Table 5

\begin{tabular}{|c|c|c|c|c|c|}
\hline $\mathbf{m} 1 \boldsymbol{a}=\mathbf{0 . 2 3 8}$ & $\lambda$ (dry) & $\begin{array}{c}\lambda \text { (wet, from } \\
\text { Fig. 8) }\end{array}$ & R (dry) & R (wet) & $\begin{array}{c}\text { Difference } \\
\text { (\%) }\end{array}$ \\
\hline TSE & 0.12 & 0.21 & 3.04 & 1.72 & 43.4 \\
\hline TSF & 0.12 & 0.22 & 3.04 & 1.66 & 45.4 \\
\hline PSE & 0.1 & 0.17 & 3.65 & 2.15 & 35.8 \\
\hline PSF & 0.1 & 0.13 & 3.65 & 2.81 & 23.0 \\
\hline
\end{tabular}

Difference between dry values and values according to the average water content for position $m 5$

Table 6

\begin{tabular}{|c|c|c|c|c|c|}
\hline $\mathbf{m 5} \boldsymbol{a}=\mathbf{0 . 0 5 2}$ & $\lambda$ (dry) & $\begin{array}{c}\lambda \text { (wet, from } \\
\text { Fig. 8) }\end{array}$ & R (dry) & R (wet) & $\begin{array}{c}\text { Difference } \\
(\%)\end{array}$ \\
\hline TSE & 0.12 & 0.17 & 3.04 & 2.15 & 29.4 \\
\hline TSF & 0.12 & 0.15 & 3.04 & 2.43 & 20.0 \\
\hline PSE & 0.1 & 0.12 & 3.65 & 3.04 & 16.6 \\
\hline PSF & 0.1 & 0.11 & 3.65 & 3.32 & 9.1 \\
\hline
\end{tabular}

\section{Conclusion}

It was demonstrated that the wind-driven rain load has crucial influence on the water content in the wall for the windward oriented facades with exterior coatings based on the traditionally cement-lime material base. The water content values, especially for the aerated clay brick, can be different for different producers because they differ in the shape of the cavities, clay etc. Moreover, the water transport model in WUFI is not ideal considering the materials with cavities (all materials in WUFI are treated as porous material). Also the difference for other manufactures of cement-lime coatings can be different. Each producer has his own manufacturing secrets and different ingredients and mixing ratios.

In the end, we offer a recommendation based on the results of the research. For the windward facades of buildings higher than 10 meters, the usage of cement-lime coatings is not recommended without any other protection (e.g. water repellent paint) because the thermal resistance will be significantly decreased.

\section{Acknowledgement}

The research is supported by the European Regional Development Fund and the Slovak state budget for the project "Research Centre of University of Zilina”, ITMS 26220220183 and VEGA No. 1/0729/13.

\section{References}

[1] BLOCKEN, B., CARMELIET, J.: A Review of Wind-driven Rain Research in Building Science. J. of Wind Engineering and Industrial Aerodynamics [online] 13/2004. pp. 1079-1130. [cit. 2010-01-10].

[2] DURICA, P., VERTAL, M.: Verification of the Water Transport Parameter - moisture Storage Function of Autoclaved Aerated Concrete - Approximately Calculated from a Small Set of Measured Characteristic Values. Communications - Scientific Letters of the University of Zilina, No. 4, 2011, pp. 35-42, ISSN 1335-4205.

[3] STN EN 15026:2007 Hygrothermal Performance of Building Components and Building Elements - Assessment of Moisture Transfer by Numerical Simulation (in Slovak).

[4] SANDERS, C.: IEA ANNEX 24, Final report, vol. 2, Task 2: Environmental conditions. Leuven, 1996. ISBN 90-75741-03-0.

[5] FRANKE, J. et al.: The Cost 732 Best Practice Guideline for CFD Simulation of Flows in the Urban Environment: A Summary. Intern. J. of Environment and Pollution [online], vol. 44, No. 1-4, 2011, pp. 419-427.

[6] JURAS. P., ZILINSKY, J.: Measurements of Wind-driven Rain Absorptivity of Various Coatings in Rain Chamber. Proc. of ATF 2013: $2^{\text {nd }}$ Conference on Acoustics, Light and Thermal Physics in Architecture and Building Structures. Leuven, Belgium 2.-3.5.2013. Katholieke Universiteit Leuven, 2013, pp. 78-84. ISBN 978-90-8649-637-2.

[7] JURAS, P. et al.: Determination of Rain Reduction Factor of Coatings. Proc. of ATF 2014: $3^{\text {rd }}$ Conference on Building Physics and Applied Technology in Architecture and Building Structures. Vienna, May, 2014. 


\section{COMMNICOIIONS}

[8] KUBILAY, A. et al.: CFD Simulation and Validation of Wind-driven Rain on a Building Facade with an Eulerian Multiphase Model. Building and Environment. [online] 61/2013, pp. 69-81 [cit. 2013-04-20].

[9] BLOCKEN, B. et al.: CFD Simulation of the Atmospheric Boundary Layer: Wall Function Problem. Atmospheric Environment [online] 41/2007, pp. 238-252 [cit. 2013-04-20].

[10] WIERINGA, J.: Updating the Davenport Roughness Classification. J. of Wind Engineering and Industrial Aerodynamics [online], 41-44/1992, pp. 357-368 [cit. 2013-04-20].

[11] HLADIK, O. et al.: Complex Effects of Free Stream Turbulence and Surface Roughness on the Transition Intermittency. Communications - Scientific Letters of the University of Zilina, No. 4A, 2012, pp. 47-52, ISSN 1335-4205.

[12] BEST, A. C.: The Size Distribution of Raindrops. QJR Meteorological Society, [online] 76/1950, p. 16-36, [cit. 2013-04-20].

[13] JURAS, P., CHVILA, B.: Experimental Measurements of Wind-driven Rain and Validation with CFD (in Slovak), Meteorologicky casopis / Meteorological J., vol. 16, No. 1, 2013, p. 33-40, Bratislava : SHMU, 2013. ISSN 1335-339X.

[14] JURAS, P. et al.: Analysis of Climate Data for Developing TRY for Bratislava. Meteorologicky casopis / Meteorological J., vol. 16, No. 1, 2013, pp. 19-23, Bratislava : SHMU, 2013. ISSN 1335-339X. 